\title{
A thymic carcinoid tumor causing Cushing syndrome in the setting of a multiple endocrine neoplasia syndrome type 1 (MEN 1)
}

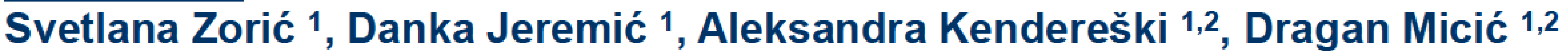 \\ 1. Clinic for Endocrinology, Diabetes and Metabolic diseases, Clinical Center of Serbia \\ Depertment for obesity, metabolic and reproductive disorders \\ 2. Faculty of Medicine, University of Belgrade
}

Ana Gligić ${ }^{1}$, Mirjana Šumarac-Dumanović ${ }^{1,2}$, Danica Stamenković-Pejković ${ }^{1,2}$, Snežana Polovina ${ }^{1}$, Goran Cvijović ${ }^{1,2}$,

\section{Introduction:}

Multiple endocrine neoplasia syndrome type 1 (MEN1) associated thymic neuroendocrine tumors (Th-NETs), namely, thymic carcinoid tumors, are rare and have poor prognosis. Cushing syndrome (CS) caused by Th-NET in MEN1 syndrome is extremely rare. Herein, we report a extremely rare case of MEN 1 syndrome, papillary thyroid carcinoma and Th-NET, presented with CS.

Objective: The aim of this clinical case report was to highlight the importance of screening MEN 1 patients for thymic carcinoid tumors that could present as ectopic Cushing syndrome.

\section{Case report:}

We report a case of a 55-year-old man with CS at presentation due to ectopic ACTH production in MEN1 syndrome. This patient had total gastric resection 30 years ago due to Zollinger-Ellison's syndrome and extirpation of two tumors of pancreas, when diagnosed with gastrinoma. The patient had a history of smoking for many years.

Three years prior to the manifestation of CS, the patient was diagnosed with primary hyperparathyroidism (PHPT) and thus treated with parathyroidectomy, near-total cervical thymectomy and total thyroidectomy. Histological analysis revealed hyperplasia of parathyroid glands, papillary thyroid carcinoma and regular thymic morphology. Based on gastrinoma and PHPT, the patient was diagnosed with MEN1 syndrome and the germline mutation of MEN1 gene was detected.

This time the patient presented with weakness, weight loss and hypokalemia $(1.9 \mathrm{mmol} / \mathrm{L})$. The results of endocrine tests for Cushing sindrome can be seen in Table 1. MDCT of the thorax revealed the large mediastinal mass (Picture 1. and 2.). Subsequently, the percutaneous biopsy of the tumor was done and the histopathological analysis revealed neuroendocrine carcinoma. The tumor was operated and the diagnosis of atypical thymic carcinoid with high proliferative activity index Ki67 (13.39\%)was confirmed. Eight months after the operation control MDCT revealed recurrent mediastinal tumor which was reoperated. Three months after the reoperation the patient developed mediastinal lymphadenopathy following no clinical and laboratory signs of Cushing syndrome.

\begin{tabular}{|c|c|c|c|c|c|}
\hline $\begin{array}{l}\text { Cortisol 08h } \\
\text { (nmol/L) }\end{array}$ & $\begin{array}{l}\text { Cortisol 20h } \\
\text { (nmol/L) }\end{array}$ & $\begin{array}{l}\text { Cortisol 24h } \\
\text { (nmol/L) }\end{array}$ & $\begin{array}{l}\text { ACTH } \\
\text { (ng/L) }\end{array}$ & $\begin{array}{l}\text { Cortisol in LDST } \\
\text { (nmol/L) }\end{array}$ & $\begin{array}{l}\text { Cortisol in HDST } \\
\text { (nmol/L) }\end{array}$ \\
\hline 582,4 & 1413,0 & 679,4 & 647,2 & 448,6 & 308,2 \\
\hline
\end{tabular}

\section{Conclusions:}

The presented case of MEN 1 is peculiar because the majority of Th-NETs in MEN1 are nonfunctional and ectopic secretion of ACTH seldom occurs. Although Th-NET did not show positive immunohistochemical staining for ACTH, level of ACTH in the blood significantly decreased after the operation. Therefore, it is not impossible that the carcinoid tumor may secrete ACTH precursors and CRH instead of ACTH. The present case highlights the importance of screening MEN1 patients for thymic carcinoid and reinforce the notion that subtotal transcervical thymectomy was not effective prophylactic tool in this case.

\section{Topic: Neuroendocrine cancer}

\section{References:}

1. Thakker RV. Multiple endocrine neoplasia type 1. In: DeGroot L, Jameson JL, eds. Endocrinology. 6th ed. Philadelphia: Elsevier 2010; $2719-2741$.

2. Brandi ML et al. Guidelines for diagnosis and therapy of MEN type 1 and type 2. J ClinEndocrinolMetab 2001; 86:5658-567.

3. Machens A et al. Age-related penetrance of endocrine tumors in multiple endocrine neoplasia type 1 (MEN1): a multicentre study of 258 gene carriers. ClinEndocrinol (Oxf) 2007 ; 67:613-622.

4. Thakker RV et al. Clinical Practice Guidelines for Multiple Endocrine Neoplasia Type 1 (MEN1). J Clin Endocrinol Metab 2012; 97: 2990-3011.

5. Takagi J, Otake K, Morishita M, et al. Multiple endocrine neoplasia type I and Cushing's syndrome due to an aggressive ACTH producing thymiccarcinoid. Intern Med 2006; 45:81-86.

6. Yano M, Fukai I, Kobayashi Y, et al. ACTH-secreting thymic carcinoid associated with multiple endocrine neoplasia type 1. Ann ThoracSurg 2006; 81:366-368.

7. Gibril F, Chen YJ, Schrump DS, et al. Prospective study of thymic carcinoids in patients with multiple endocrine neoplasia type 1. J ClinEndocrinolMetab 2003; 88:1066-1081

8. Manes JL, Taylor HB. Thymic carcinoid in familial multiple endocrine adenomatosis. Arch Pathol 1973: 95:252-255.

9. Rosai J, Higa E. Mediastinal endocrine neoplasm of probable thymic origin, related to carcinoid tumor. Clinicopathologic study of 8 cases. Cancer $1972 ; 29: 1061-1074$.

10.Rosai J, Higa E, Davie J. Mediastinal endocrine neoplasm in patients with multiple endocrine adenomatosis. A previously recognized assotiation. Cancer 1972; 29: 1075-1083.

11. Hasani-Ranjbar S et al. Ectopic Cushing syndrome associated with thymic carcinoid tumor as the first presentation of MEN1 syndrome-report of a family with MEN1 gene mutation.

. Familiant

12. Goudet $P$ et al. Thymic neuroendocrine tumors in multiple endocrine neoplasia type 1: a comparative study on 21 cases among a series of 761 MEN1 from the GTE (Groupe des

13. Oberg K, Jelic S. Neuroendocrine bronchial and thymic tumors: ESMO clinical recommendation for diagnosis, treatment and follow-up. Ann Oncol $2008 ; 19$ (Suppl 2):102-103.

14. Hirai S et al. Thymic Carcinoids in Multiple Endocrine neoplasia type 1. JJTCVS 2001; 49: 525-527.

15.Kim H-J et al. A Case of Multiple Endocrine Neoplasia Type 1 Combined with Papillary Thyroid Carcinoma. Yonsei Med J 2008; 49(3):503-506. 